\title{
Attitude of pediatricians and family physicians regarding vitamin $D$ supplementation for the pediatric population: when, how much, and at what dose?
}

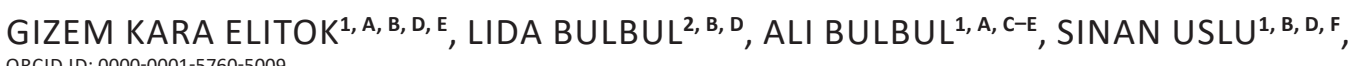
ORCID ID: 0000-0001-5760-5009

\author{
UMUT ZUBARIOGLU ${ }^{1, B, F}$, EVRIM KIRAY BAS ${ }^{1, B, F}$, DUYGU BESNILI ACAR ${ }^{1, B, F}$
}

\author{
${ }^{1}$ Department of Pediatrics, University of Health Sciences, Sisli Hamidiye Etfal Education and Research Hospital, \\ Istanbul, Turkey \\ ${ }^{2}$ Department of Pediatrics, University of Health Sciences, Bakırköy Sadi Konuk Education and Research Hospital, \\ Istanbul, Turkey
}

A - Study Design, B - Data Collection, C - Statistical Analysis, D - Data Interpretation, E - Manuscript Preparation, F - Literature Search, G - Funds Collection

Summary Background. The association of sub-optimal vitamin D level with many diseases, such as cardiovascular diseases, diabetes mellitus, cancer, autoimmunity, and infectious diseases, is demonstrated in the studies.

Objectives. We aimed to evaluate the knowledge and attitudes of physicians who worked in pediatric health on vitamin $\mathrm{D}$ supplementation. Material and methods. The study was conducted between April and May 2015 with the participation of 574 pediatricians and family physicians. A 13-question form was completed during face-to-face interviews with the participants. The approval of the ethics board was granted.

Results. 217 pediatricians (37.8\%) and 357 family physicians (62.2\%) participated in the study. In total, $85.2 \%(n=185)$ of pediatricians and $92.4 \%(n=330)$ of family physicians recommended vitamin D supplementation to infants and children regardless of their nutrition type. Vitamin D supplementation was recommended to children who had a disease that would cause metabolism disorders by $20.3 \%$ $(n=44)$ of pediatricians and $21.3 \%(n=76)$ of family physicians. A $400 \mathrm{IU} /$ day dose was recommended by $89.4 \%(n=194)$ of pediatricians and $76.8 \%$ ( $n=274)$ of family physicians. $70 \%$ of pediatricians $(n=152)$ and $62.7 \%(n=224)$ of family physicians initiated the supplementation of vitamin $D$ when infants were 15 days old. The rate of recommendation of vitamin $D$ of family physicians $(67.8 \%$, $n=242)$ until the age of one year was higher than that of pediatricians $(44.7 \%, n=97) .9 .7 \%(n=21)$ of pediatricians and $10.4 \%(n=$ 37) of family physicians recommended vitamin $D$ supplementation until fontanel closure.

Conclusions. This study suggests that the knowledge of physicians who work in pediatrics on the practice of vitamin D supplementation, starting time, and duration must be updated.

Key words: physicians, family, vitamin D, pediatricians, child, attitude.

Elitok GK, Bulbul L, Bulbul A, Uslu S, Zubarioglu U, Bas EK, Acar DB. Attitude of pediatricians and family physicians regarding vitamin D supplementation for the pediatric population: when, how much, and at what dose? Fam Med Prim Care Rev 2018; 20(4): 332-336, doi: https://doi.org/10.5114/fmpcr.2018.79343.

\section{Background}

The association of sub-optimal vitamin D level with many diseases, such as cardiovascular diseases, diabetes mellitus, cancer, autoimmunity, and infectious diseases, in addition to the effect on bone health, is demonstrated in the studies [1]. Vitamin $D$ deficiency is a global health problem in developing countries $[1,2]$. The causes of vitamin $D$ deficiency in infants and children are maternal vitamin $D$ deficiency, inadequate intake in diet, inadequate exposure to sun, breastfeeding, and rapid growth $[2,3]$.

The resources of vitamin $D$ in infants are through placental transition, breast milk, and dermal synthesis from sunlight $[2,4$, 5]. One liter of breast milk contains 15-50 IU vitamin D and is inadequate for the daily need of infants [2]. Infants must consume at least 1 liter of formula to have adequate amounts of vitamin D [6]. The American Academy of Pediatrics (AAP) recommended vitamin $D$ supplementation to all infants who consumed less than 1 liter of formula, breast milk, and mixed feeding (breast milk + formula) in 2008 [6]. Therefore, prevention of vitamin D deficiency in infancy and childhood is highly significant in providing vitamin D supplementation $[3,7]$.

'The prevention of vitamin D deficiency and protection of bone health project' has been conducted in Turkey since 2005. In accordance with the project, free daily 400 IU vitamin D supplementation has been provided to all infants until the age of one year [4]. The prevalence of rickets was $6 \%$ before the program and has since decreased to $0.1 \%$ [8]. Although there has been a decrease in the prevalence of rickets, the prevalence vitamin D deficiency is still high. Researchers reported that about one third of children did not receive vitamin D supplementation due to various reasons, such as discontinuation by physicians, mothers unwilling or forgetting to give the doses, and children refusing to accept the drops $[9,10]$.

\section{Objectives}

The health workers' role of initiation of vitamin D supplementation, and the persistence of supplementation, is important in the prevention of vitamin D deficiency, in addition to free 
vitamin D supplementation in prevention strategies of vitamin $D$ deficiency. In the present study, we aimed to identify the knowledge and attitudes of pediatricians and family physicians on vitamin D supplementation through interviews.

\section{Material and methods}

\section{Study design}

We planned a descriptive, cross-sectional study to assess physicians' attitudes and knowledge levels regarding vitamin D supplementation.

\section{Setting and variables}

The study was carried out between April and May 2015 in Istanbul. The sample consisted of 574 physicians who participated in the study. The approval of the Local Ethics Board (490/2015) was granted for the study.

The questionnaire form was prepared by two expert pediatricians, taking into consideration recent literature. The 13-question questionnaire was completed during face-to-face interviews with the participants. Four researchers completed the interviews in two months. Their academic title, time of graduation from university, which infants and children they recommended vitamin $D$, why, when, and for how long they recommended vitamin $D$, whether they took into consideration the season when recommending vitamin $D$, and the dose and method they recommended were questioned.

\section{Participants}

Pediatricians and family physicians who were actively working were included in the study. The answers of both groups were compared.

\section{Statistical methods}

The Statistical Package for the Social Sciences 15.0 for Windows was used for statistical analysis. Descriptive statistics are given as number and percentage for categoric variables. The ratio comparisons in independent groups were performed using chi-square analysis. Monte Carlo simulation was performed when the conditions could not be provided. The statistical alfa significance level was accepted as $p<0.05$.

\section{Results}

632 participants were interviewed during the study; 43 refused to participate, and 15 were excluded because they did not answer the majority of questions. A total of 574 physicians consisting of 217 pediatricians (37.8\%) and 357 family physicians $(62.2 \%)$ participated in the study. The demographic characteristics of the participants are shown in Table 1 . Table 2 presents the distribution of participants' responses to the questions regarding to whom and why they recommended vitamin D.

The pediatricians' recommendation rate of vitamin $\mathrm{D}$ supplementation was higher than that of family physicians to 'infants who were only fed with breastmilk' $(p=0.004)$. The family physicians' rate of recommendation of vitamin $D$ 'to all children irrespective of their feeding' was higher than that of pediatricians $(p=0.048)$. The rate of recommendation for vitamin D supplementation of pediatricians 'for preventing diseases' was higher than that of family physicians $(p=0.002)$ (Table 2$)$.

\begin{tabular}{|c|c|c|c|}
\hline & & $n$ & $\%$ \\
\hline \multirow[t]{2}{*}{ Specialty } & pediatrician & 217 & 37.8 \\
\hline & family physician & 357 & 62.2 \\
\hline \multirow[t]{5}{*}{ Institution type } & family health center & 210 & 36.6 \\
\hline & public hospital & 37 & 6.4 \\
\hline & $\begin{array}{l}\text { training and research } \\
\text { hospital }\end{array}$ & 246 & 42.9 \\
\hline & university & 65 & 11.3 \\
\hline & private hospital & 16 & 2.8 \\
\hline \multirow{4}{*}{$\begin{array}{l}\text { Total years of } \\
\text { graduation from } \\
\text { university }\end{array}$} & less than 5 years & 187 & 32.6 \\
\hline & between $5-10$ years & 137 & 23.9 \\
\hline & between $11-20$ years & 152 & 26.5 \\
\hline & more than 20 years & 98 & 17.1 \\
\hline
\end{tabular}

Table 2. The distribution of participants' opinions on vitamin D supplementation recommendations

\begin{tabular}{|c|c|c|c|c|}
\hline & & $\begin{array}{l}\text { Pediatri- } \\
\text { cian } \\
n=217\end{array}$ & $\begin{array}{l}\text { Family } \\
\text { physician } \\
n=357\end{array}$ & $p$ \\
\hline & & \multicolumn{3}{|c|}{$n(\%)$} \\
\hline \multirow{3}{*}{$\begin{array}{l}\text { Effect of } \\
\text { nutrition on } \\
\text { recommend } \\
\text { vitamin D } \\
\text { supplemen- } \\
\text { tation? }\end{array}$} & $\begin{array}{l}\text { disregarding the } \\
\text { feeding type }\end{array}$ & $\begin{array}{l}185 \\
(85.2)\end{array}$ & $\begin{array}{l}330 \\
(92.4)\end{array}$ & 0.048 \\
\hline & only breastfed & $29(13.4)$ & $20(5.6)$ & 0.004 \\
\hline & only baby formula & $3(1.4)$ & $7(2)$ & 0.197 \\
\hline \multirow{4}{*}{$\begin{array}{l}\text { To which in- } \\
\text { fants do you } \\
\text { recommend } \\
\text { vitamin D } \\
\text { supplemen- } \\
\text { tation? }\end{array}$} & $\begin{array}{l}\text { to infants and } \\
\text { children with } \\
\text { less exposure to } \\
\text { sunlight }\end{array}$ & $51(23.5)$ & $108(30.3)$ & 0.080 \\
\hline & $\begin{array}{l}\text { disease that may } \\
\text { cause disorders in } \\
\text { vitamin D metabo- } \\
\text { lism }\end{array}$ & $44(20.3)$ & $76(21.3)$ & 0.772 \\
\hline & $\begin{array}{l}\text { those experienc- } \\
\text { ing frequent } \\
\text { respiratory tract } \\
\text { infections }\end{array}$ & $14(6.5)$ & $22(6.2)$ & 0.890 \\
\hline & $\begin{array}{l}\text { those with fatigue } \\
\text { and muscle pain }\end{array}$ & $15(6.9)$ & $22(6.2)$ & 0.723 \\
\hline \multirow{5}{*}{$\begin{array}{l}\text { Why do you } \\
\text { recommend } \\
\text { vitamin D } \\
\text { supplemen- } \\
\text { tation to } \\
\text { infants and } \\
\text { children? }\end{array}$} & $\begin{array}{l}\text { for prevention of } \\
\text { rickets and vita- } \\
\text { min D deficiency }\end{array}$ & $201(92.6)$ & 339 (95) & 0.251 \\
\hline & $\begin{array}{l}\text { for closure of } \\
\text { fontanel }\end{array}$ & $21(9.7)$ & $33(9.2)$ & 0.863 \\
\hline & $\begin{array}{l}\text { due to vitamin } D \\
\text { supplementation } \\
\text { program }\end{array}$ & $2(0.9)$ & $48(13.4)$ & $<0.001$ \\
\hline & $\begin{array}{l}\text { for prevention of } \\
\text { infections }\end{array}$ & $40(18.4)$ & $34(9.5)$ & 0.002 \\
\hline & other* & $9(4.1)$ & $11(3.0)$ & \\
\hline
\end{tabular}

Other*: 5 physicians recommended due to inadequate vitamin $D$ in breast milk, 5 for walking in shorter time, 3 for supporting immune system, 2 for protection of allergic diseases, 2 for prevention of hypertension and depression, 2 for prevention of chronic disease and cancer, and 1 due to the recommendation of the World Health Organization. 
The distribution of responses to questions about the time, duration, method, and dose of vitamin D supplementation, and whether they considered seasonal changes in dose regulations, are presented in Table 3. A statistical difference was detected in the group distribution of participant physicians and initiation time of vitamin $D$ supplementation $(p<0.001)$. The initiation of vitamin D supplementation of pediatricians was higher 'immediately after birth' and 'at 15 days old'; however, family physicians' vitamin D supplementation initiation rates were higher 'in the first month' and 'in month three' (Table 3).

We found that the vitamin D supplementation recommendations of pediatricians were higher until the age of two years and over three years of age; however, the family physicians' rate of recommendation was higher until one year of age and until closure of the fontanel $(p<0.001)$ (Table 3).

\begin{tabular}{|c|c|c|c|c|}
\hline & & $\begin{array}{l}\text { Pediatri- } \\
\text { cian }\end{array}$ & $\begin{array}{l}\text { Family } \\
\text { physician }\end{array}$ & $p$ \\
\hline & & \multicolumn{3}{|l|}{$n(\%)$} \\
\hline \multirow{5}{*}{$\begin{array}{l}\text { When do you } \\
\text { recommend } \\
\text { vitamin } D \text { ? }\end{array}$} & $\begin{array}{l}\text { immediately } \\
\text { after birth }\end{array}$ & $\begin{array}{l}50 \\
(23.0) \\
\end{array}$ & $\begin{array}{l}59 \\
(16.5) \\
\end{array}$ & \multirow[t]{5}{*}{$<0.001$} \\
\hline & $\begin{array}{l}\text { in the first } \\
15 \text { days after } \\
\text { birth }\end{array}$ & $\begin{array}{l}152 \\
(70.0)\end{array}$ & $\begin{array}{l}224 \\
(62.7)\end{array}$ & \\
\hline & in month 1 & $9(4.1)$ & $45(12.6)$ & \\
\hline & in month 3 & $5(2.3)$ & $26(7.3)$ & \\
\hline & other & $1(0.5)$ & $3(0.8)$ & \\
\hline \multirow{5}{*}{$\begin{array}{l}\text { For how } \\
\text { long do you } \\
\text { recommend } \\
\text { vitamin D } \\
\text { supplementa- } \\
\text { tion? }\end{array}$} & $\begin{array}{l}\text { until closure of } \\
\text { fontanel }\end{array}$ & $21(9.7)$ & $37(10.4)$ & \multirow[t]{5}{*}{$<0.001$} \\
\hline & $\begin{array}{l}\text { until } 6 \text { months } \\
\text { of age }\end{array}$ & $3(1.4)$ & $9(2.5)$ & \\
\hline & $\begin{array}{l}\text { until } 1 \text { year of } \\
\text { age }\end{array}$ & $\begin{array}{l}97 \\
(44.7) \\
\end{array}$ & $\begin{array}{l}242 \\
(67.8) \\
\end{array}$ & \\
\hline & $\begin{array}{l}\text { until } 2 \text { years } \\
\text { of age }\end{array}$ & $\begin{array}{l}80 \\
(36.9) \\
\end{array}$ & $\begin{array}{l}52 \\
(14.6) \\
\end{array}$ & \\
\hline & $\begin{array}{l}3 \text { years and } \\
\text { above }\end{array}$ & $16(7.4)$ & $17(4.8)$ & \\
\hline \multirow{5}{*}{$\begin{array}{l}\text { At which } \\
\text { dose do you } \\
\text { recommend } \\
\text { vitamin } D \text { ? }\end{array}$} & daily $200 \mathrm{IU}$ & $2(0.9)$ & 39 (10.9) & \multirow[t]{5}{*}{$<0.001$} \\
\hline & daily 400 IU & $\begin{array}{l}194 \\
(89.4) \\
\end{array}$ & $\begin{array}{l}274 \\
(76.8) \\
\end{array}$ & \\
\hline & daily $600 \mathrm{IU}$ & $14(6.5)$ & $34(9.5)$ & \\
\hline & $\begin{array}{l}\text { drinking am- } \\
\text { pule forms }\end{array}$ & $1(0.5)$ & $5(1.4)$ & \\
\hline & no comment & $6(2.8)$ & $5(1.4)$ & \\
\hline \multirow{3}{*}{$\begin{array}{l}\text { Do you rec- } \\
\text { ommend dif- } \\
\text { ferent doses } \\
\text { of vitamin D } \\
\text { in accordance } \\
\text { with the } \\
\text { season? }\end{array}$} & only in winter & $7(3.2)$ & $12(3.4)$ & \multirow[t]{3}{*}{0.034} \\
\hline & $\begin{array}{l}\text { all through } \\
\text { the year; } \\
\text { higher doses in } \\
\text { winter }\end{array}$ & $\begin{array}{l}82 \\
(37.8)\end{array}$ & $\begin{array}{l}98 \\
(27.5)\end{array}$ & \\
\hline & $\begin{array}{l}\text { same dose all } \\
\text { through the } \\
\text { year }\end{array}$ & $\begin{array}{l}128 \\
(59.0)\end{array}$ & $\begin{array}{l}247 \\
(69.2)\end{array}$ & \\
\hline \multirow{4}{*}{$\begin{array}{l}\text { The preferred } \\
\text { method of } \\
\text { vitamin D } \\
\text { supplementa- } \\
\text { tion? }\end{array}$} & drop & $\begin{array}{l}182 \\
(83.9)\end{array}$ & $\begin{array}{l}334 \\
(93.6)\end{array}$ & \multirow[t]{4}{*}{0.001} \\
\hline & $\begin{array}{l}\text { drop + multivi- } \\
\text { tamin }\end{array}$ & $22(10.1)$ & $18(5.0)$ & \\
\hline & drop + ampule & $2(0.9)$ & $1(0.3)$ & \\
\hline & multivitamin & $11(5.1)$ & $4(1.1)$ & \\
\hline
\end{tabular}

The rate of pediatricians' daily recommendation of 400 IU vitamin $\mathrm{D}$ was higher $(89.4 \%, n=194)$ than the rate of family physicians $(76.8 \%, n=274)(p<0.001)$. The family physicians' rate of recommendation of daily $200 \mathrm{IU}$ and $600 \mathrm{IU}$ vitamin D supplementation was higher than that of pediatricians (Table 3).

The rate family physicians' vitamin D supplementation 'all year at the same dose' and pediatricians' rate of 'higher doses in winter' were both high $(p=0.034)$ (Table 3$)$.

\section{Discussion}

The American Academy of Pediatrics (AAP) and the Turkish Pediatric Endocrine Society recommended vitamin D supplementation to all infants regardless of their feeding type $[4,6]$. Researchers reported that only half of family physicians (54\%) and most pediatricians (85\%) behaved in compliance with this consensus $[11,12]$. We found that pediatricians and, particularly, most family physicians were compliant with this consensus report. However, the pediatricians in our study recommended vitamin D supplementation to infants who were fed with only breast milk at strikingly low rates $(13.4 \%, n=29)$.

Vitamin D deficiency may be detected in diseases that cause chronic fat absorption, such as celiac disease, cystic fibrosis, and chronic liver diseases, because vitamin D is a fat-soluble vita$\mathrm{min}$. Long-term use of steroids and anticonvulsant drugs has negative effects on vitamin D metabolism. Daily $400 \mathrm{IU}$ vitamin D supplementation is inadequate in these children; however, high-dose vitamin $D$ supplementation (at least two-three times more) may enable normal levels of vitamin $D[6,13]$. In our study, we detected that the rate of recommendation of vitamin D supplementation "in children with a disease that may damage vitamin D metabolism" was low among both pediatricians and family physicians.

The American Institute of Medicine recommends $400 \mathrm{IU} /$ /day of vitamin D before the age of one year, and $600 \mathrm{IU} /$ day after the age of one year [14]. The AAP updated their vitamin D recommendation as $400 \mathrm{IU} /$ day in 2008, which they had previously recommended as $200 \mathrm{IU} /$ day in 2003 [6]. Some publications reported that there was a decrease in the level of $25 \mathrm{OH}$ vitamin $\mathrm{D}$ in the winter period, and vitamin $\mathrm{D}$ supplementation less than $400 \mathrm{IU} /$ day was inadequate $[15,16]$. Therefore, the Canadian Paediatric Society reported that people living in northern latitudes in particular ( $55^{\text {th }}$ parallel north and above) must receive $800 \mathrm{IU} /$ day vitamin D supplementation between October and April [17]. Researchers in a study conducted in the city of Kocaeli, located in Northern Turkey, found that $400 \mathrm{IU} /$ day vitamin D supplementation increased the level of $25 \mathrm{OH}$ vitamin $\mathrm{D}$ to $>20 \mathrm{ng} / \mathrm{mL}$ [18]. Researchers reported that the use $400 \mathrm{IU} /$ /day of vitamin D was effective in the prevention of vitamin D deficiency in Turkey, irrespective of seasonal difference $[4,18]$. The majority of pediatricians and family physicians recommended daily $400 \mathrm{IU}$ vitamin D supplementation regardless of seasonal difference in compliance with this recommendation. Researchers in a recent study reported that the majority $(75.5 \%)$ of pediatricians recommended daily $400 \mathrm{IU}$ vitamin D supplementation [19]. In addition, we detected that some of the pediatricians and family physicians recommended 600 IU vitamin D supplementation in our study. Furthermore, family physicians recommended daily 200 IU vitamin D at a considerably high rate.

Maternal and infant serum $25 \mathrm{OH}$ vitamin D levels are correlated in the first eight weeks of life [5]. Researchers demonstrated that the most significant risk factor for low $25 \mathrm{OH}$ vitamin D levels in newborns was maternal $25 \mathrm{OH}$ vitamin D levels $<10 \mathrm{ng} /$ $/ \mathrm{mL}(\mathrm{OR}=15.2, p=0.02)$ [20]. Maternal vitamin $\mathrm{D}$ deficiency was detected at a level of $80 \%$ in Turkey in other studies [9, 21, 22]. Therefore, initiation of vitamin $D$ supplementation to infants from the first days of life has been recommended [4-6]. Studies that investigated the initiation period of vitamin D supplementation reported that $14 \%$ of family physicians began supplementation immediately after birth and $41 \%$ in the first month, whereas $28.7 \%$ of pediatricians initiated supplementation im- 
mediately after birth, and $47.3 \%$ initiated it at the end of the second week $[11,19]$. Similar to these studies, we detected that pediatricians and family physicians initiated vitamin D supplement at high rates, and initiation of vitamin D supplementation immediately after birth was lower. Furthermore, family physicians initiated vitamin $D$ supplementation in the first or third month at significant rates. This period is regarded as late for the initiation of vitamin D supplementation. These results suggest that education programs must be organized concerning when to initiate vitamin D supplementation.

Different opinions have been suggested on the duration of vitamin D supplementation. The AAP recommended that vitamin D supplementation must be initiated following birth and should be continued through childhood, including adolescence [6]. Previously, $39 \%$ of family physicians recommended vitamin D supplementation at least for one year, $21 \%$ recommended for 6 months, and $7.4 \%$ for 9 months, and the rate of vitamin D supplementation until 36 months was detected as only $1 \%$ [11]. We observed that about half of the pediatricians in our study recommended vitamin $D$ supplementation until the age of one year, and one third of pediatricians recommended vitamin $D$ until the age of two years. In the present study, the rate of recommendation of vitamin D supplementation for children aged three years and above was low among pediatricians and family physicians. We suggest that education programs must be organized to espouse a longer period of vitamin $D$ supplementation.

Researchers suggested a regular follow-up of head circumference measurement in cases of fontanel closures with unknown reasons, because brain development is rapid in the first two years of life [23]. Fontanels vary in shape and closure time in children $[24,25]$. Fontanels may be wider than normal in children with rickets, and delays may be detected in closure $[10,24]$. No studies in literature have reported that administration of maintenance doses of vitamin D had an effect on early closure of fontanels. In this respect, discontinuation of vitamin $D$ because the fontanel is small or maintenance of vitamin $D$ supplementation until closure of the fontanel is not correct practices. Researchers reported that $19.9 \%$ of pediatricians discontinued vitamin $D$ supplementation because the fontanel was small [19]. In the current study, both pediatricians and family physicians recommended vitamin D supplementation at signifi- cant rates for "fontanel closure" and considered fontanel closure as the time to discontinue vitamin $D$ supplementation. This recommendation might cause early discontinuation of vitamin D supplementation for children whose frontal fontanel closure was before the age of one year.

\section{Limitations of the study}

The collection of data was made by a questionnaire which was performed by clinicians. As the results of the study depend to personal knowledge, the data was obtained in a subjective manner. In addition, the study was performed only in Istanbul. Lack of objectivity in collection of data and accomplishment of study only in one city should be listed as limitations of our study.

\section{Conclusions}

We detected that a majority of pediatricians and family physicians recommended $400 \mathrm{IU} /$ day vitamin D supplementation to all infants and children. Some pediatricians were detected to recommend vitamin $\mathrm{D}$ to infants only fed with breast milk. The rate of recommendation of vitamin $D$ was lower among pediatricians and family physicians in children diagnosed with diseases that might damage vitamin $D$ metabolism. A majority of pediatricians and family physicians initiated vitamin $D$ supplementation when the infant was 15 days old; however, the rate of initiation of vitamin D supplementation immediately after birth was low in both groups. Vitamin D supplementation was mainly recommended until the age of one in both groups, and the rate of recommendation of vitamin $D$ supplementation to children aged three years and above was found to be lower. We detected that pediatricians and family physicians recommended vitamin $D$ supplementation for fontanel closure at significantly higher rates or discontinued vitamin D supplementation after fontanel closure.

The data of our study revealed that the knowledge of physicians working in pediatric health on the practice of vitamin $D$ supplementation, initiation time, and duration must be updated. Organization of education programs for health workers is required, in addition to enabling free vitamin $D$ supplementation, among the strategies for the prevention of vitamin D deficiency.

Source of funding: This work was funded by the authors' own resources. Conflict of interest: The authors declare no conflict of interests.

\section{References}

1. Pludowski P, Holick MF, Pilz S, et al. Vitamin D effects on musculoskeletal health, immunity, autoimmunity, cardiovascular disease, cancer, fertility, pregnancy, dementia and mortality - a review of recent evidence. Autoimmun Rev 2013; 12: 976-989.

2. Misra M, Pacaud D, Petryk A, et al. Drug and Therapeutics Committee of the Lawson Wilkins Pediatric Endocrine Society. Vitamin D deficiency in children and its management: review of current knowledge and recommendations. Pediatrics 2008; 122: 398-417.

3. Holick MF. Resurrection of vitamin D deficiency and rickets. J Clin Invest 2006; 116: 2062-2072.

4. Hatun Ş, Özkan B, Bereket A. Vitamin D deficieny and prevention: Turkish experience Acta Paediatr 2011; 100: 1195-1199.

5. Hatun S, Ozkan B, Orbak Z, et al. Vitamin D deficiency in early infancy. J Nutr 2005; 135: 279-282.

6. Wagner CL, Greer FR. Prevention of rickets and vitamin D deficiency in infants, children and adolescents. Pediatrics 2008; 122 : 1142-1152 .

7. Hochberg Z, Bereket A, Davenport M, et al. European Society for Paediatric Endocrinology (ESPE) Bone Club. Consensus development for the supplementation of vitamin D in childhood and adolescence. Horm Res 2002; 58: 39-51.

8. Ozkan B, Doneray H, Karacan M, et al. Prevalence of vitamin D deficiency rickets in the eastern part of Turkey. Eur J Pediatr 2009; 168: 95-100.

9. Türkiye'de 6-17 Aylık Çocuklarda ve Annelerinde Hemoglobin Ferritin D - Vitamini Düzeyi ve Demir Eksikliği Anemisi Durum Belirleme Yürütülen Programların Değerlendirilmesi Araştırması. Ankara: Sağlık Bakanlığı Yayınları; 2011: 79-88. Available from: URL: http:// cocukergen.thsk.saglik.gov.tr/Dosya/Dokumanlar/Kitaplar/Demir_DVitamini_2011_Arastirma_Raporu/Demir_D-Vitamini_2011_ Arastirma_Raporu.pdf (in Turkish).

10. Gülez P, Korkmaz HA, Özkök D, et al. Factors influencing serum vitamin D concentration in Turkish children residing in İzmir: a SingleCenter Experience. J Clin Res Pediatr Endocrinol 2015; 7: 294-300.

11. Toprak GD, Hatun Ş. D Vitamini Yetersizliği ve D Vitamini Desteği Konusunda Pratisyen Hekimlerin Tutumları. Sürekli Tıp Eğitimi Dergisi 2004; 13: 16-18 (in Turkish).

12. Pehlivan I, Toprak DG, Hatun Ş. Ülkemizdeki Çocuk Hekimlerinin D Vitamini Desteği ve Raşitizm Konusundaki Tutumları. Çocuk Dergisi 2004; 4: 42-45 (in Turkish). 
13. Garcia-Careaga M, Kerner JA. Evaluation of children with suspected intestinal malabsorption. In: Behrman RE, Kliegmen RM, Jenson HB, eds. Nelson textbook of pediatrics $17^{\text {th }}$ ed. Philadelphia: Saunders; 2003: 1257-1272.

14. Ross AC, Manson JE, Abrams SA, et al. The 2011 report on dietary reference intakes for calcium and vitamin $D$ from the Institute of Medicine: what clinicians need to know. J Clin Endocrinol Metab 2011; 96: 53-58.

15. Halicioglu $\mathrm{O}$, Sutcuoglu $\mathrm{S}$, Koc F, et al. Vitamin D status of exclusively breastfed 4-month-old infants supplemented during different seasons. Pediatrics 2012; 130: e921-e927.

16. Gross ML, Tenenbein M, Sellers EA. Severe vitamin D deficiency in 6 Canadian First Nation formula-fed infants. Int $J$ Circumpolar Health 2013; 72: 20244, doi: 10.3402/ijch.v72i0.20244.

17. Godel JC. Canadian Paediatric Society First Nations, Inuit and Métis Health Committee. Vitamin D supplementation: recommendations for Canadian mothers and infants. Paediatr Child Health 2007; 12: 583-589.

18. Yeşiltepe Mutlu G, Kusdal Y, Ozsu E, et al. Prevention of Vitamin D deficiency in infancy: daily $400 \mathrm{IU}$ vitamin $\mathrm{D}$ is sufficient. Int J Pediatr Endocrinol 2011; 2011(1): 4, doi: 10.1186/1687-9856-2011-4.

19. Karabulut SG, Hatun Ş, Bideci A, et al. Attitudes of pediatricians regarding prevention and treatment of vitamin $D$ deficiency. $J$ Clin Res Pediatr Endocrinol 2016; 8: 368-371.

20. Andıran N, Yordam N, Özön A. The risk factors for vitamin D deficiency in breastfed newborns and their mothers. Nutrition 2002; 18: 47-50.

21. Ergür AT, Berberoğlu M, Atasay B, et al. Vitamin D deficiency in Turkish mothers and their neonates and in women of reproductive age. J Clin Res Pediatr Endocrinol 2009; 1: 266-269.

22. Halicioglu $\mathrm{O}$, Aksit $\mathrm{S}$, Koc F, et al. Vitamin D deficiency in pregnant women and their neonates in spring time in western Turkey. Paediatr Perinat Epidemiol 2012; 26: 53-60.

23. Mutlu EC, Akın L, Akın MA, et al. Closed fontanel due to wormian borne: case report. Erciyes Medical Journal 2011; 33: 65-68 (in Turkish).

24. Kiesler J, Ricer R. The abnormal fontanel. Am Fam Physician 2003; 67: 2547-2552.

25. Duc G, Largo RH. Anterior fontanel: size and closure in term and preterm infants. Pediatric 1986; 78: 904-908.

Tables: 3

Figures: 0

References: 25

Received: 18.05.2018

Reviewed: 16.06 .2018

Accepted: 25.06 .2018

Address for correspondence:

Gizem Kara Elitok, MD

Department of Pediatrics

Sisli Hamidiye Etfal Education and Research Hospital

Halaskargazi cad. Sisli, Istanbul

Turkey, 34371

Tel.: +90 5327310173

E-mail: drgizemkara@gmail.com 